\title{
CANADIAN MUSLIMS AND CANADA'S DOMESTIC AND FOREIGN POLICY ISSUES: AN ANALYSIS
}

\author{
Syed Serajul Islam and Ishtiaq Hossain*
}

\begin{abstract}
This article analyses the participation of Canadian Muslims in debates affecting Canada's domestic and foreign policy issues. Here, the Canadian Muslim identity is first of all briefly spelled out. Then a detailed discussion is made of their role in debates affecting the country's domestic affairs. In addition, the Canadian foreign policy issues which are of interest to Canadian Muslims are identified and their stand on those issues are analysed. The discussion in this article demonstrates that the Muslim citizens of Canada are conscious of their own Canadian Muslim identity. It also shows that, like other Canadians, the Muslim citizens of Canada express their opinion freely on matters, which are of importance to the country. Although their impact on policy-making remains negligible, their increasing participation in the political process of the country beacons hope for their more lasting impact on the country's public policy-making in future.
\end{abstract}

\section{Introduction}

From a mere 13 males who identified themselves as Muslims in the 1871 Canadian Census, ${ }^{1}$ by 2006 the Canadian Muslims numbered more than one million. ${ }^{2}$ With the passage of time Canadian Muslims have become increasingly involved in national, provincial, and local politics. Nowadays, they do not only voice out their own Canadian Muslim identity strongly, but also take part eloquently in debates on the country's domestic and foreign affairs. This article starts out by discussing the Canadian Muslims' views about themselves, then explains separately the stand taken by the Canadian Muslims on key domestic and foreign policy issues in Canada.

\section{Canadian Muslim Identity}

In the post-September 2001 world, Muslims feel that they are under siege and that their religion, culture, and honour are under attack. The angry and often violent protests that erupted in Muslim communities across the globe during the winter of

* Syed Serajul Islam is a Professor in the Department of Political Science at Lakehead University, Thunder Bay, Ontario, Canada, and Ishtiaq Hossain is an Associate Professor in the Department of Political Science at the International Islamic University Malaysia (IIUM). 
2005-2007, in response to the publication by a Danish newspaper of caricatures of the Prophet Muhammad, underlined that siege mentality. These protests, unfortunately, also confirmed for many in the West a long-held belief about Islam: that it is a violent, stern, glowering, and humourless religion. ${ }^{4}$ There is also an entrenched view in the West that Prophet Muhammad is responsible for giving rise to the negative views about Islam. Maghen rejects this view and argues that Prophet Muhammad and his Companions cannot be held responsible for this kind of negative views. ${ }^{5}$ In fact, the classical sources of the Islamic canon point to a vastly different picture of the atmosphere and dynamics of informing the ideal Muslim community - a picture of relaxed cheerful, jocular, even feisty and frolicsome individuals who enjoyed the good things in life and never took themselves seriously. ${ }^{6}$ Meghen further argues that far from leaving the foundations for a cult of the sombre, solemn, and sedate - of the fierce, furious, and fanatical - the Prophet of Islam and his followers presented the world with something unprecedented at the time, and never since approximated; a religion that knows how to laugh. ${ }^{7}$

A small section of Canadian people share the widely-held view in the West that the followers of Islam are puritanical holy warriors, fanatics, dervishes, suicide bombers, hijackers and human waves thrown into battle. ${ }^{8}$ A Toronto-based think tank, the Mackenzie Institute, in a report describes Islam as undeniably the most violent of the World's universal religions. ${ }^{9}$ The report goes on to portray Prophet Muhammad as a trader, and a successful warlord who sent his followers out to bring fire and sword to all who denied his message. ${ }^{10}$ Such negative views of Islam and Muslims are not healthy and certainly do not contribute to the building of a rational understanding of their problems in Canada. It must, however, be pointed out that the majority of Canadians reject such negative views of Islam and believe that there is no 'clash of civilisations' as portrayed by the late Samuel P. Huntington or clash of religions among the three Abrahamic faiths - Christianity, Judaism, and Islam. In fact, the majority of Canadians believe that Canadian Muslims play positive roles in national affairs. This is borne out by a poll carried out in 2006 by the Pierre Elliott Trudeau Foundation. This poll found out that 75 percent of Canadians taking part in that poll believed that the Canadian Muslim immigrants make positive contributions to Canada. ${ }^{11}$

Canada, like the United States and Australia, is a nation of immigrants. Canadian Muslims, just like other groups of immigrants of the country, are increasingly trying to discover their self-identities in Canadian society. After much soul-searching, the Canadian Muslims have come to realise that they are not only Muslims with distinctive characteristics, but are also Canadians sharing the pursuits of life and happiness as their other fellow Canadians. A good example would be the case of Sumaira Sheikh, a Canadian journalist with family roots in Pakistan and North Africa. She describes the creation of Canada as an artificial construct and depicts the 
country as a manifestation of an immigrant society where an immigrant, regardless of how long she has lived in it, still retains her immigrant status. ${ }^{12}$ This view is in response to a commonly held misunderstanding in Canada that one cannot really be Canadian if not white. However, like other immigrants who have made Canada their abode, Sheikh and others like her, firmly believe that Canada is their home and their ancestral places are not, though the latter have nourished their national identities. When they talk about making changes to their country, they do not think of any other country, but Canada.

Canada is a country of diverse cultures and multi-faith communities. Muslim immigrants settled in Canada in search of a better economic life and opportunities. Many of them also migrated to Canada escaping political, economic, and ethnic persecution in their homelands. Like Sumaira Sheikh, the Canadian-born children of the first generation Muslim immigrants feel strongly connected to the Canadian culture, and at the same time are aware of their own cultural roots. The young secondgeneration and third-generation Canadian Muslims do not view Canada as a nihilistic force seeking to destroy Islamic tradition. Rather, they believe that a multi-cultural and multi-religious Canada offers them a good opportunity to be a practicing Muslim as well as a Canadian.

\section{Domestic Issues of Concern to Canadian Muslims}

There are a number of important domestic issues which are of interest to Canadian Muslims. In this section an analysis is made of their involvement in shaping the political discourse on the following: (a) the Maher Arar Case; (b) the independent inquiry of torture in Syria of three foreign-born Canadians; (c) the Anti-Terrorism Act; (d) the Toronto Terrorism Case of 2006; (e) Huseyin Celil's life-sentence in China; (f) the participation of Muslims in the recent Canadian election; and (h) the controversy over reasonable accommodation.

\section{The Maher Arar Case}

The case of Maher Arar, a Syrian-born Canadian haunted not only the Canadian Muslims, but ordinary Canadians as well. He was a victim of extraordinary rendition. On 26 September 2002, he was detained at New York's John F. Kennedy airport by United States officials when his flight from Zurich arrived there enroute to Montreal. After being questioned about his alleged links with al-Qaeda and held at a Detention Centre in New York for twelve days, Arar was told he would be deported to Syria. Arar protested that he would be tortured in Syria and since he was a Canadian, he be sent back to Canada. However, on 8 October 2002, he was flown in a private jet to Jordan and then driven in a van to Syria and handed over to Syrian military intelligence officials. ${ }^{13}$ 
Following his return to Canada on 5 October 2003, Maher Arar claimed that he had been tortured during his incarceration in Syria. He accused the American officials of sending him to Syria in spite of their knowledge that he would be tortured there by the Syrian military intelligence officials. Arar's plight shocked the Canadian Muslims as did their fellow Canadians. There was also a lot of sympathy for Arar's demand that the Canadian federal government pay compensation to him because Arar alleged that the Canadian officials did not do enough to stop his deportation to Syria from New York. Judge Dennis O'Connor of Ottawa ordered an inquiry into the affair.

Judge O'Connor presented his first report on 18 September 2006. In his report Judge O'Connor made scathing remarks of the behaviour of the Royal Canadian Mounted Police (RCMP). He found that the RCMP, without any justification, had labelled Arar as an "Islamic extremist linked to al-Qaeda", and then shared this information with the American law enforcing agencies. The Judge concluded that it was likely that in arresting Arar in New York and sending him to Syria, the US authorities relied on the false information provided to them by the RCMP. In his first report, the judge also recommended twenty-three specific steps to be taken to correct the human rights abuses and failures which had led to Arar's arrest in New York. Many of these recommendations dealt with the prevention of disregarding the rule of law, deficient investigative practices, irresponsible labelling, racial profiling, arbitrary arrest and detention and the practice of torture. To this date, there is no report on the implementation of recommendations contained in Judge O'Connor's report.

On 12 December 2006 Judge O'Connor's second report was released to the public. In it, he made strong recommendations to establish a comprehensive review and oversight mechanism for security and intelligence operations in Canada. It is not that Canada lacks review bodies to oversee intelligence operations in the country. However, these have diverse mandates and are narrowly focused. These have obviously failed to protect Arar from abuses. Judge O'Connor's recommendations would provide greater assurance that security and intelligence activities respect the rule of law, due process and human rights standards.

In view of Judge O'Connor's reports, Canada's Prime Minister Stephen Harper then issued a formal apology to Maher Arar while announcing a compensation package amounting to C $\$ 12.5$ million for him. The compensation package included $\mathrm{C} \$ 10.5$ million for his pain and suffering, and another C $\$ 2$ million for Arar's legal fees. Prime Minister Harper also wrote a personal letter of regret to Arar and wished him and his family a new start in their lives. The Canadian Prime Minister wrote to the authorities in Washington and Damascus to protest Arar's treatment. On 5 December 2006 Royal Canadian Mounted Police (RCMP) Commissioner Giuliano Zaccardell appeared before the Canadian Parliament's House of Commons Committee on Public Safety and National Security. In an extraordinary move, he admitted that he had made a mistake when he gave inaccurate testimony about 
Arar's case to the Committee in September. The very next day he submitted his resignation to Prime Minister Harper.

Canadian Muslims were worried about Arar's case mainly because his detention in New York by US officials and his subsequent deportation to Syria fit into the standard stereotyping that Muslims have been subjected to and implied that they had no human rights and that they could be detained/arrested and tortured without any accountability. They were also angry because none other than the RCMP Commissioner had admitted misleading the elected officials of the Canadian people about Arar's case. The Canadian Muslims had expected a higher degree of professionalism from the RCMP. Their frustration and anger were amply reflected in an opening statement of the CAIR-CAN and the CAF before the Commission of Inquiry into the Actions of Canadian Officials in Relations to Maher Arar. The statement pointed out that the "Muslims and Arabs across the country identify with Mr. Arar because his account parallels the accounts they have heard from families, friends, and neighbours of the arbitrary abuses they have suffered. They understand racial profiling because they have been targets of it. They understand what it means to be victims of discrimination. They understand what it means to be treated as suspects in the war on terrorism. ${ }^{14}$ No matter how angry the Canadian Muslims were of the Arar case, they were pleased with Prime Minister Harper's public apology to Arar and his family. This gesture took the wind out of the Muslim public anger on the issue.

\section{The Independent Inquiry of Three Syrian-Born Canadians Tortured in Syria}

Judge O'Connor's inquiry came across three other cases similar to that of Maher Arar. Three Arab-Canadians - Abdullah Almalki (Syrian-born), Muayyed Nureddin (Iraqiborn) and Ahmad El Maati (Kuwaiti-born) - were all arrested in Syria, detained, and tortured in the same prison as Arar. They were released on 21 October 2006 without charge and returned to Canada. Since Judge O'Connor did not have the mandate to investigate these three cases, he recommended for the setting up of a separate enquiry commission to look into these three cases. Therefore, on 12 December 2006 the Canadian Federal Public Safety Minister Stockwell Day announced the launching of an independent inquiry into the Actions of Canadian Officials in Relation to Abdullah Almalki, Ahmad Abou-Elmati, and Muyaaed Nureddin. The inquiry was to be led by former Supreme Court Judge Frank Icobucci.

There has been much criticism of Judge Frank Icobucci's Commission's lack of transparency. Unlike the Arar inquiry, much of Judge Iacobucci's Commission of Inquiry conducted its business in camera even when the issues were not strictly related to national security issues. Even the three men affected and their lawyers were shut out of the process and had no access to information. After nearly two years 
of inquiry, Judge Iacobucci Commission's report was released on 21 October 2008. The report unequivocally found that the three men were tortured and documented the many ways that the "deficient" conduct of Canadian officials contributed to the grave human rights violations the three men experienced. Judge Iacobucci expressed serious concerns about repeated and unjustified labelling of these men as imminent threats, associates of Osama bin Laden, Islamic extremists, and terrorists. He concluded that these labels were inaccurate, inflammatory, unreliable and lacked investigative basis. He opined that the Canadian government must finally deliver justice to these men and act to ensure that no other citizen suffers the same fate.

\section{The Anti-Terrorism Act}

The Anti-Terrorism Act (C-36) has been a source of controversy ever since its adoption by the Canadian Parliament in December 2001. The Act not only defines "terrorism" and makes it a punishable offence under Canada's Criminal Code, it also contained provisions dealing with preventive detention (up to three days), arbitrary arrest, investigative hearings, listing of alleged terrorist groups, delisting of charitable organisations, suspensions of the right to remain silent, and the principle of innocence until proven guilty. These provisions are in contravention of the International Covenant on Civil and Political Rights (ICCPR), in particular, Articles 9, 14, 17 and 18 .

Since its adoption in 2001 certain articles of the Anti-Terrorism Act have been altered by Court decisions and parliamentary amendments and the Act itself has not yet been applied extensively or successfully. However, the attitude that inspired it and the threat of its use has had serious consequences. For example, the original inclusion of reference of religion as a motivational factor in the definition of terrorism has led to people's religious life being under investigation. Sometimes the Canadian police, intelligence officers, and other officials have carried out their duties with an attitude of unwarranted suspicion and irresponsible labelling, including religious and racial profiling, especially against Arab and Muslim Canadians (for example, the Arar case). Further, the very passage of and continued promotion of these exceptional measures by the government has intimidated certain segments of the Canadian people with respect to their rights and has had a chilling effect on religious practice and on the funding and programme of civil society organisations dealing with international development and human rights advocacy.

The Public Safety Act (C-17) adopted by the Canadian Parliament in 2004 is a companion to the Anti-Terrorism Act of 2001. It contains provisions for increased information-sharing within and between governments as well as measures relating to aviation security, the control of toxins, and other dangerous materials, terrorist financing, disclosures of privacy information with respect to airline passengers, 
expanded emergency measures, and a substantial increase in intrusive investigative procedures.

The Canadian Immigration and Refugee Protection Act (IRPA) provides for the issuance of Security certificates by the Minister of Immigration and the Minister of Public Safety leading to the detention and deportation of a permanent resident or a foreign national deemed to be inadmissible on security or certain criminal grounds. The definition of security inadmissibility is extremely broad, including people who are not alleged to represent any security danger (for example, those who are merely members of an organisation that is believed to have committed terrorist acts). A judge may review the Certificate to determine if it is reasonable to issue such a Certificate. The review is based on intelligence, not on evidence as generally required in a trial.

The Anti-Terrorism Act was the subject of heated debate among the Muslim communities when five Muslims were arrested under Security Certificates. Neither the accused nor their lawyers had had the opportunity to examine the alleged charges. Muslims around Canada were outraged and a coalition of Muslim organisations protested against the Anti-Terrorism Act and Security Certificates. On 23 February 2007 the Supreme Court of Canada ruled that the non-disclosure of evidence provided for in the reviews of cases under Security certificates contravened the Canadian Charter of Rights and Freedoms and decreed that a fair hearing leading to detention must include the right to know the case against one and the right to answer the case.

In February 2008, the Canadian Parliament passed a law to offset the 2007 Supreme Court ruling and to resurrect the Security Certificate process. The key difference between the new law and the one ruled unconstitutional is the provision of Special Advocates to protect the interests of the persons named in the Certificates at the review process. However, these Advocates do not have the right to discuss the evidence with the persons subject to the certificate. In these circumstances, these Security Certificates still contravene the Canadian Charter of Rights and Freedoms. The person(s) affected is still held in detention without trial, does not have the right to know the case against him nor the right to answer that case. Four of the five Muslim men subject to the Certificate have been released on bail under highly restrictive conditions, and one remains in detention.

\section{The 2006 Toronto Terrorism Case}

On June 2, 2006, the Integrated National Security Enforcement Team (INSET) task force led the RCMP, the Canadian Security Intelligence Service (CSIS), the Ontario Provincial Police (OPP) and other police forces, into a series of counter-terrorism raids in Greater Toronto Area and arrested eighteen alleged members of a purported Islamic terrorist group. It was alleged by the Canadian law enforcement agencies that these men had been planning a series of major terrorist attacks on targets in 
southern Ontario. They were accused of planning to detonate truck bombs, to open fire in a crowded area, and to storm the Canadian Parliament Building in Ottawa, the Canadian Security Intelligence Service (CSIS) headquarters, and the parliamentary Peace Tower, to take hostages and to behead the Prime Minister and other leaders.

The media in Canada, at the beginning, was careful in making any judgement on the merit of the case. In fact, Robert Fisk in Globe and Mail was of the opinion that nothing had been proven and warned of rushing to judgement. ${ }^{15}$ The federal government made it very clear that it was not in a rush and had given the court the time to conduct a fair trial. The stand of the Muslim community was clear: the leaders of the Muslim community condemned any attempts to harm fellow Canadians through violent means. In a statement twenty-two Imams of Canada condemned extremism, and reminded Canadian Muslims that no injustice done to Muslims anywhere can ever justify the taking of innocent life. As religious leaders, they echoed the exhortation of the Qur'ān for Muslims to be firm advocates for justice, even if it be against their families, their communities or themselves and to insist on Islam as a living reality that is compassionate, tolerant and life sanctifying.

It was only after the end of the jury trial of the case in June 2010 that details of the case were revealed by Isabel Teotonio of the Toronto Star. ${ }^{16}$ It contained the details on guilty pleas and convictions. The investigations began with the Canadian intelligence officials monitoring Internet chat sites. The arrested individuals were being monitored by the CSIS since 2004, and it was later joined by the RCMP. Although the intelligence officials could not find any direct links, the individuals were alleged by CSIS to have been inspired by Al Qaeda. The US Joint Terrorism Task Force had become involved in the investigation by March 2005. The individuals were charged under the 2001 Anti-Terrorism Act.

Six of the seventeen men arrested had ties to the Al-Rahman Islamic Centre near Toronto. Another two of those arrested were already serving prison time in Kingston, Ontario on weapons possession charges. According to the US Federal Bureau of Investigation (FBI), two other men, who were arrested in Atlanta, Georgia in the U.S. on terrorism charges, were connected to the case as well. In September 2008, Nishanthan Yogakrishnan, charged as a youth when arrested, was convicted of knowingly participating in, and contributing to, a terrorist group and plotting to detonate truck bombs in downtown Toronto and storm Parliament Hill. In May 2009, he was sentenced as an adult to two and a half years of time of imprisonment. He was the first person to be found guilty under Canada's 2001 Anti-Terrorism Act. In May 2009, Saad Khalid pleaded guilty to aiding a plot to detonate a bomb in Toronto's downtown, the Toronto Stock Exchange, the CSIS headquarters in Toronto, and an unidentified military base, off Highway 401 between Toronto and Ottawa. He was sentenced to 14 years in prison. In September 2009, Ali Mohamed Dirie, a Somaliborn Canadian admitted he was a member of a terrorist group that planned attacks 
in Canada. On tape, he called white people the "number one filthiest people on the face of the planet. They don't have Islam. They are the filthiest people." He added, "In Islam there is no racism, we only hate kufur (non-Muslims) [sic!; the correct Arabic expression is kuffär]." The Crown and the defence had agreed on a seven-year sentence. ${ }^{17}$ So far, the courts have convicted four men, and charges against seven other individuals have been stayed or dropped.

One of the controversial aspects of the Toronto terrorist case was the involvement in the alleged plot by Mubin Shaikh - a police informant. He was born in Toronto, the son of immigrant parents who migrated to Canada in the 1970s. It was in his late teens that Mubin became a devout follower of Islam as he was "burned out" from the life he was living. ${ }^{18}$ In an interview with the CBC's Fifth Estate, Mubin complained that people began to treat him differently as an identifiable Muslim after the 9/11 attacks on New York and Washington, and it nearly drove him to join the war in Afghanistan and Chechnya. However, he did not and became a well-known figure among the Muslims in the Toronto area. Described as a devout Muslim, he was part of the movement that failed the attempt to introduce sharì $a h$ law for civil cases for Muslims in Ontario. According to Mubin, he stayed in Syria during 2002-2004, and following his return to Toronto from Syria, he contacted the CSIS in March 2004. Preferred to be called an 'informant' rather than a 'spy', Mubin penetrated the Toronto terror plotters, and supplied information about them to the intelligence agencies.

In the mainstream Canadian media, Mubin Shaikh has been lauded as a 'hero'. However, within the Canadian Muslim community, Mubin's role in nabbing the Toronto plotters has become a subject of much speculation. Questions have been raised over Mubin's real aims, since he admitted that a large sum of money had been promised to him for his actions. Issues have also been raised about "entrapment" by members of the Toronto plotters. Instead of using his inside view and his knowledge to counsel the young men and warn them against terrorist actions, he engaged in discussions with the group about jihad and led the very 'training camps' that generated much media attention. His very active participation in the group raises concerns about the extent to which he could have influenced the accused individuals to engage in terrorist acts they might not have committed on their own. ${ }^{19}$

\section{Huseyincan Celil's Life-Sentence in China}

In 2006, Huseyincan Celil, a Canadian and a Chinese citizen of Uighur origin, was sentenced to life by a Chinese court following a highly controversial trial. Huseyincan was arrested in Uzbekistan in 2006 while on a family visit and then extradited to China against strong objections of the Canadian government. He was charged and convicted of "terrorism" and other related crimes. He was a political activist 
while living in Xinxiang. He was arrested by the Chinese authorities in Xinxiang in 1994 and charged with several murders and terrorism-related activities and was imprisoned by the Chinese police. He escaped from China by way of Kyrgyzstan and Turkey and sought asylum in Ankara through the United Nations High Commissioner for Refugees (UNHCR). After the UNHCR gave him refugee status, the Canadian Government in turn granted him the same and allowed him to live in Canada. He arrived in Canada in 2001 and acquired Canadian citizenship and lived in Hamilton, Ontario.

In November 2006, Canadian Prime Minister Harper attended the Asia-Pacific Economic Cooperation (APEC) Summit in Hanoi, Vietnam. At that meeting Harper discussed Celil's case with President Hu Jintao of China. Harper reportedly told Hu, "When a Canadian citizen is taken from a third country and imprisoned in China this is a serious concern to this country." ${ }^{20}$ The dispute between the two countries over Celil's continued imprisonment in China has left its mark on Canadian-Chinese relations. While the Chinese officials insist that their trade relations with Canada should go hand-in-hand with political relations, the Canadian officials point out that since the balance of trade is in favour of China, Beijing should pay more attention to this and see that issues like the continued imprisonment of Celil do not change that.

\section{The Case of Omar Khadr}

The case of Omar Khadr has attracted the attention of all Canadians, irrespective of their religious and ethnic backgrounds. The issues surrounding this case are two: whether he received a fair trial at the hands of the United States Military Commission at Guantanamo Bay and whether the Canadian Government should have brought him back home to stand trial. On 25 October 2010, Omar Khadr, a Canadian citizen, as part of a pre-trial deal, pleaded guilty before a US Military Commission at Guantanamo Bay to murder and attempted murder in violation of the laws of war, conspiracy to commit terrorism, providing material support for terrorism, and spying and was sentenced to eight years imprisonment.

The trial of Omar Khadr, began on 12 August 2010, but adjourned for a month as his defence lawyer Lt. Col. Jon Jackson collapsed in court and had to be hospitalised. Now 23, Omar was only 15 when he was arrested by US forces in 2002 in Afghanistan. Prosecutors charged Omar as an al-Qaeda militant and throwing grenades at Sgt. Christopher Speer and killing him. However, his defence lawyer argued Omar Khadr himself was a victim. According to him, Omar's family had links with Osama bin Laden and forced Omar Khadr to take part in fighting the Americans in Afghanistan. According to the Americans, Omar's father, Ahmed Syed Khadr, was an al-Qaeda financier and was killed in Pakistan in 2003 in a fire fight. During the jury selection process, the trial judge made it clear to the prosecution that in order to 
get a conviction, they had to prove that Omar had the intention to commit the crimes he was accused of. However, he granted the prosecution's request to present Omar's confession recorded at Bagram Air Base after his arrest. Omar's defence lawyer had argued that this confession had to be thrown out because it was allegedly extracted under coercion and mistreatment, making it unreliable and inadmissible.

A trial that Omar should stand, but the question was whether he would get a fair trial at Guantanamo Bay. According to two former Guantanamo Bay prosecutors - Col. Morris Davis (the Chief Prosecutor) and Lt. Col. Darrel Vandeveld - the Guantanamo Bay judicial process was unfair and resigned in protest in October 2007 and September 2008 respectively. Even Presidential candidate Barack Obama thought that the Guantanamo Bay judicial process was flawed. However, the Canadian Prime Minister Stephen Harper took a position that was at odds with the majority public opinion on the question. He refused to intervene in Omar Khadr's case stating that he needed to face his charges through a judicial process, not a political one. Convinced that Omar should be brought back to Canada to stand trial, a litigation process was initiated in Canada to remind the Canadian government of its responsibility towards one of its citizens. On 29 January 2010 the Supreme Court of Canada gave its verdict in Prime Minister of Canada v Omar Khadr. The Court found that Canada's actions offended the most basic Canadian standards about the treatment of detained youth suspects and required the government to grant Omar a remedy.

\section{Controversy over Reasonable Accommodation}

By any standard, Canadian multiculturalism has thus far been a remarkable success as it has woven a highly diverse population, drawn from the four corners of the planet, into a peaceful prosperous and remarkably cohesive society. ${ }^{21}$ The mastermind of Canadian multiculturalism is philosopher Charles Taylor who has been advocating such a philosophy since the 1960s. The Canadian policy of multiculturalism is based on the assumption that in liberal, democratic immigration societies such as Canada, it is one of the state's core responsibilities to protect and encourage cultural diversity. ${ }^{22}$ The policy of multiculturalism has allowed a million new arrivals to the country every four years or so to maintain aspects of the cultures of their countries of origin while adapting to their new home. ${ }^{23}$ However, since the last few years, rumbles have been heard from sections of the Canadian society regarding the integration of immigrants into the society and the rights of the immigrants.

Lars von Torne, a German journalist from the Berlin newspaper Der Tagesspiegel, was shocked by the intensity of insults hurled between immigrants and Canadianborn Montrealers during a dialogue session in Montreal organised by the Consultation Commission on Accommodation Practices Related to Cultural Differences. ${ }^{24}$ At that dialogue session, Canadian-born citizens complained about the building of increasing 
number of mosques in their neighbourhoods and accused the Muslim community of forcing young girls to wear headscarves. While the immigrant Muslims retorted that they did not want to change their way of life and asked that they be not told what to do. ${ }^{25}$

The debate over reasonable accommodation in Canada started at the beginning of 2007 in Quebec and soon spread to Ontario. The term 'reasonable accommodation' is used in Canada to refer to the theory that equal rights set out in provincial and federal anti-discrimination laws and in section 15 of the Canadian Charter of Rights and Freedoms demand that accommodation be made for various minorities. There are, at least, two explanations for the emergence of the debate on reasonable accommodation in Canada.

According to the first explanation, the debate surrounding 'reasonable accommodation' emerged in a particular political and social context in Quebec. These circumstances, it is argued, helped make visible the racist and sexist nature of government policies towards indigenous peoples and immigrants since the colonisation of Canada. ${ }^{26}$ It also accused the Quebec government of turning the immigrants issue into a public debate in the media. ${ }^{27}$ It points out that the debate over reasonable accommodation took place in a political and social context mediated heavily by Quebec nationalism and issues of identity such as 'integration of immigrants', 'secularism', 'multiculturalism', and 'cultural and religious minorities' in Quebec. It is alleged that those issues were raised by depicting the immigrant communities through highly mediatised and arguably anecdotal instances of reasonable accommodation and by putting forward the stereotype that Muslim women are victims of their own culture and religion. ${ }^{28}$

The second explanation for the debate on 'reasonable accommodation' is based on the argument that it is being taken advantage of by the immigrants. For example, in Quebec, when a Supreme Court of Canada decision allowed a Sikh boy to wear an appropriately sheathed kirpan (a ceremonial sword) while attending public school, protests were heard from political elites. They argued that carrying a ceremonial sword is a threat to public safety and therefore, should not be allowed. It was followed by seemingly endless streams of cases in which members of religious minorities were perceived to have received some unfair advantages (prayer rooms in their educational institutions, dispensations from rules banning headdresses in sporting events, etc.) under the legal doctrine of "reasonable accommodation" of their Charter rights. ${ }^{29}$ In Ontario, a similar furore was unleashed by the publication of Marion Boyd's report on shari 'ah courts, which led Premier Dalton McGuinty to decree that religious arbitration of family law matters would not be allowed in any shape or form in the province. ${ }^{30}$

In order to deal with public anxieties over 'reasonable accommodation' on 8 February 2007, Quebec Premier Jean Charst announced the establishment of the Consultation Commission on Accommodation Practices Related to Cultural 
Differences. Two of Quebec's leading intellectuals, philosopher Charles Taylor and sociologist Gerard Bouchard were named to head the Consultation Commission. It had a mandate to a) take stock of accommodation practices in Quebec b) analyse the attendant issues bearing in mind the experience of other societies c) conduct an extensive consultation on this topic and d) formulate recommendations to the government to ensure that accommodation practices conform to Quebec's values as a pluralistic, democratic, egalitarian society. ${ }^{31}$

The Commission, in addition to commissioning research projects carried out by specialists from Quebec and holding sessions with experts, held four Quebec-wide hearings lasting for 31 days. The Commission's report Building the Future: A Time for Reconciliation was drafted by Bouchard and Taylor between January and March 2008. Among others, the report's recommendations focus on the following key areas: 1) The report calls for a definition of new policies or programmes pertaining to inter-culturalism (as multiculturalism is understood in Quebec) and secularism. 2) A number of recommendations were made on the central theme of integration and focus primarily on a) recognition of immigrants' skills and diplomas b) francisation programmes $\mathrm{c}$ ) the need for more sustained efforts to regionalise immigration and d) the need for enhanced coordination between government departments. 3) Another priority area identified by the report is the fight against inequality and discrimination against the immigrants. In this regard the report's recommendations focus on a) the under-representation of ethnic minorities in the government b) the urgency of combating the various forms of discrimination, 'islamophobia', anti-Semitism and the racism to which radicalised groups, especially Blacks are subjected to c) the support to be offered to immigrant women and d) the strengthening of economic and social rights in the Quebec Charter.

The Report reinforces a point made by Stein, that is, that Canada must develop a deep, rather than a shallow, multiculturalism. ${ }^{32}$ The publication of the Report undoubtedly is important, but the implementation of its recommendations will not be easy. As Stein points out there are three challenges that must be taken by the Canadians to build a multiculturalism that would be ready to meet the needs of changing socioeconomic realities of life in Canada. First, according to Stein, Canadians must attend to the overlap between cultural and economic boundaries. ${ }^{33}$ It has to be admitted that unlike the older generations of immigrants, the new immigrants to Canada find it hard to find jobs and integrate economically. It is a worrying trend because the inability to integrate economically can lead to reinforcement of one's ethnic and religious identity. One of the reasons for the new groups of immigrants' inability to find jobs is the non-recognition of their professional degrees and diplomas. It is not unusual to find new immigrants with degrees in engineering and other professional degrees driving taxis in cities like Toronto, Vancouver and Montreal. There is a need for the Canadian government to rethink its policy of non-recognition of degrees of such countries as Iran. 
Second, Stein points out that the cultural groups in Canada must be encouraged to build bridges rather than enclaves. ${ }^{34}$ It is natural that in an immigrant society like that of Canada, de facto neighbourhood desegregation is most likely to happen. Unlike the Jewish community, the Muslims in Canada, however, have largely avoided it. They have lived in mixed neighbourhood and their children have attended schools along with other religious and ethnic groups. However, it needs to be pointed out that in the post-9/11 period, Canadian Muslims have tended to move away from their previous practice. Now, some of them like to live in the same neighbourhood and provide religious education to their children. It also needs to be recognised that there is nothing wrong in providing religious education. However, it may be problematic when enclave mentality takes over.

Third, Stein advises Canadians to engage in the difficult dialogue that has to do with the conflicts between culture and religion, on the one hand, and the rule of law on the other. ${ }^{35}$ Perhaps this is the most difficult challenge for Canadian multiculturalism. It involves a number of issues considered part and parcel of each community. For example, under Canadian law gender equality is guaranteed and equal opportunity is offered to every Canadian irrespective of their gender. If cultural and religious considerations prevent young females from getting formal education, then the laws should guide the issues. These are often difficult issues and need to be tackled carefully. The issue of wearing of head scarves by Canadian Muslim women is a case in point. In the wake of the debate over "reasonable accommodation", secular Canadian Muslims pushed for the adoption of laws banning headscarves in public. They argued such practices were against Canadian values. If practices of communities do not contradict the basic laws Canadian laws, then each community should be allowed to work out its practices. It needs to be pointed out only a small proportion of Muslims in Canada choose to put a public face to their religious beliefs by wearing hija $\bar{b}$ and very few of them ask for reasonable accommodation. Is it really plausible that to claim that accommodations granted to a handful of people represent a threat sufficient to warrant the limitation of religious freedom? Can one claim with a straight face that the accommodation, say, of a hijäb-wearing Muslim girl might spread to the majority of the Muslim population and beyond? Above and beyond the question of symbols and of the moral sensitivities of members of the cultural and religious majority, what are the concrete risks that exist for Quebec society from respecting the religious freedoms of a very small number of people? ${ }^{36}$

\section{Foreign Policy Issues}

Howard Leeson describes Canadians as a people who cautiously consider everything, looking for all of the options before they commit themselves to a course of action. ${ }^{37}$ Canadian Muslims are no exceptions to this. They are also very cautious in suggesting 
course of actions to be taken by Canada and also careful to express their opinions on foreign policy issues of the country. It goes without saying that Canadian Muslims do not yet play any direct role in the nation's public life and foreign policy-making. However, it is to be noted that Canadian Muslims have served their country with distinction as civil servants, diplomats and soldiers. This nationalism for Canada drives their views on Canadian domestic and foreign policy issues. Canadian Muslims, though represented by different organisations, agree on the over-all belief that "better world might look like a better Canada." ${ }^{38}$ They are also wedded to a three-pillar approach to Canadian foreign policy. These pillars are: Canadian security within a stable global framework, promotion of prosperity and employment, and promotion of cultural values cherished by Canadians such as secularism, individualism and democracy. ${ }^{39}$

Liat Redcliff Ross's study is one of the very few available on Canadian Muslims and Canadian foreign policy. ${ }^{40}$ Ross examines the foreign policy interests of two leading Canadian Muslim groups - the Canadian Islamic Congress (CIC) and the Council on American-Islamic Relations Canada (CAIR-CAN) during the period 2000-2005. These organisations were chosen, as Ross explains, because of their access to federal government ministers, politicians, and policymakers, and are prolific contributors to the national media. ${ }^{41}$ However, it must be pointed out that Ross does not claim that the interests and views of these two organisations represent those of Canadian Muslims in general. Nevertheless, the opinions of these two organisations are important because the Canadian ruling elites consider these two organisations as the spokespersons of Canadian Muslims.

Ross's study reveals that smart integration, media engagement, human rights, and educating Muslims of Canada about the country's political institutions are the primary objectives of both organisations. However, Mohamed Elmasry, CIC's founding president made it clear that foreign policy remains a concern for the Muslim communities in Canada ${ }^{42}$ Like CAIR-CAN and CIC, the Canadian Arab Federation (CAF) also does not include foreign policy as its main aim. Established in 1967, the CAF is a national non-partisan, non-profit and membership-based organisation which represents Canadian Arabs on issues relating to public policy. CAF aims to raise awareness of domestic issues that affect the Arab community in Canada through education, public awareness, media relations and non-partisan government relations. However, though not solely established for the sake of expressing their voices on Canadian foreign policy issues, the CIC, CAIR-CAN and the CAF remain active in voicing their opinions on Canada's foreign policy issues of particular interest to the Canadian Muslims, for example, the Arab-Israeli conflict, the conflicts in Afghanistan and Iraq, and 2006 Israeli invasion of Lebanon and the 2008 Israeli War on Gaza. 


\section{The Arab-Israeli Conflict}

Canadian Muslims, like the rest of the Muslims around the world, are concerned about the following issues pertaining to the Arab-Israeli conflict: a final peace settlement between the Palestinians and the Israelis; the continued occupation of Palestinian territories by Israel; the plight of Palestinians in Gaza Strip due to Israel's continued blockade of the territory and the loss of Palestinian civilian life and the destruction of properties of civilians in Gaza during Israel's military assault on Gaza starting on 27 December 2008.

Overall, the Canadian Muslims acclaim that since the days of Lester Pearson, Canada has enjoyed a reputation of being a quintessential peace-keeper, a protector of human rights, a promoter of international law and a provider of humanitarian aid. They also praise the values that underline Canada's prized reputation as the driving force in persuading the international community in accepting Canada's 'Responsibility to Protect' principle at the United Nations (UN).

The CAF finds that while Canada's foreign policy has been commendably developed within the framework of international human right laws, it has become apparent that its stated policies on the Middle East - Palestine and Israel - in particular are inconsistent with its actions on the world stage via Canada's UN recent voting patterns and public statement. ${ }^{43}$ According to CAF, this problematic double standard casts doubt on Canada's position as being a fair and effective player on the international stage. ${ }^{44}$ The CAF agrees with several of Canada's written policies on the Middle East, but it is critical of Canada's "inconsistent" application of its own policies and principles when it relates to Israel. The CAF is troubled by Canada's weak position on Israel's occupation of Palestinian territories and Israel's serious human rights record when it comes to voting on UN resolutions condemning these violations. ${ }^{45}$ In order to make its opinion heard on the Parliament Hill in Ottawa, the CAF has to compete with the Jewish organisations in Canada and develop in-roads into the Canadian political system. Otherwise, such statements will remain just as opinions.

The general living conditions and human rights violations of the Palestinians living in Gaza and the West Bank are of immense concerns to Canadian Muslims. After a thirteen-day trip in 2005 to the West Bank and Gaza Strip, Wahida C. Valentine, the president of CIC, released a report entitled Living Conditions in the Gaza Strip and the West Bank. Funded by the Jerusalem Fund of Canada, and part of a medical campaign, her trip was designed to identify areas for community development, education, and training. She found it most alarming and disturbing at the general level of pessimism expressed by men, women, and youth about the state of economy and the future of the peace process. ${ }^{46}$ She established that the Israeli monopoly on export and import was a serious threat to living conditions of the Palestinians due to high taxes on imported goods, and difficulties in exporting Palestinian-made goods. 
In her report, Valentine recognised that charities in Canada such as Jerusalem Fund for Human Societies (JFHS) could play a vital role in augmenting the lives of orphans and poor families through the establishment of educational institutions in partnership with local non-governmental organisations. She firmly believed that the Muslim community in Canada and the Canadian government could partner with JFHS to sponsor and finance projects that are specifically geared toward young people.

Israel's economic and social blockade of Gaza, though relaxed in 2010 after an international outcry after Israel Defence Forces (IDF) soldiers boarded a Turkish ship delivering humanitarian aid to Gaza and killed nineteen Turkish humanitarian aid workers, has crippled the normal life of Palestinians living in Gaza. The blockade has prevented adequate supplies of food, medicine, water, and fuel to the 1.5 million inhabitants of Gaza. Facing daily humiliations of occupation, the Gaza inhabitants suffer from impoverishment. The hard hit is the children of Gaza. Fifteen to twenty percent of them are stunted in growth due to malnutrition and forty percent suffer from insomnia.

The people of Gaza suffered most when Israel launched a vicious military assault on Gaza in December 2008. According to Israel this attack was launched in response to launching of crude rockets on Israeli towns by extremist groups from Gaza. Though crude, these rockets occasionally killed and wounded Israeli civilians. The result of Israeli military attacks on Gaza was inevitable. More than 1000 civilians, including children were killed in Gaza. Homes, schools and other infrastructures were destroyed. Many civilians wounded in the attacks died because of the lack of medicines and proper medical equipment. In a joint statement the CAC and the CAF declared the Israeli attacks as clear "war crime" and considered Israel's behaviour in Gaza as blatant violation of the fourth Geneva Convention. The CIC and the CAF condemned the collective punishment of people of Gaza and called on all Canadians and people of conscience everywhere to condemn the Israeli "crimes" in Gaza. ${ }^{47}$ Khaked Mouammar, the CAF national president, said, "The Canadian Government and the United Nations are under both a legal and moral obligation to compel Israel to cease its actions against Gaza and to ensure respect for international law and protect civilian life". ${ }^{48}$

\section{Lebanon}

The 2006 Israeli invasion of southern Lebanon and the merciless air attacks on Beirut destroyed much of its infrastructures and killed 1150 civilians in the country. The massive military onslaught on Lebanon was brought on when Hezbollah forces killed one Israeli soldier and kidnapped three others. Canada refused to join the other UNmember states to call for an immediate cease-fire. According to the CAF, the refusal by Canada to call for an immediate cease-fire had endangered the lives of nearly fifty thousand Canadian citizens living in Lebanon. ${ }^{49}$ The majority of these citizens, however, were evacuated safely along with other foreigners from Lebanon. 
The CAF holds the view that under pressure from the pro-Israel lobby and the US government, Canada has banned both Hamas and Hezbollah. The CAF considers both these groups as legitimate political parties, with grassroots support. It also points out that these Palestinian groups are resisting the "illegal Israeli occupation of Palestine and Lebanon respectively." ${ }^{50}$ The CAF appealed to Canada to reverse its decision to list Hezbollah as a terrorist organisation and wanted to clarify its position on Hamas because "Hamas was democratically elected by the Palestinian people."

\section{The Iraq War}

The 2003 American invasion and occupation of Iraq was opposed by both the government and the people of Canada. Although allied to the US through its membership of NATO, Canada refused to join Washington in its military action against Iraq. Ottawa supported a UN-sponsored solution to the Iraq crisis in 2003. The Canadian people considered this position as a principled one. Muslims in Canada think the "illegal" American invasion and occupation of Iraq was the main cause for the escalation of violence in the country and civilian deaths. Canadian Muslims praised the Canadian government for providing more than US\$300 million in funding as reconstruction aid to Iraq.

\section{The War in Afghanistan}

Canada's military involvement in Afghanistan began in October 2001 when Prime Minister Jean Chretien ordered the launching of 'Operation Apollo' designed to assist American war effort in Afghanistan. More than 2,500 Canadian soldiers were sent to Afghanistan, and the Navy deployed four warships in the Arabian Sea. Canadian troops working under the command of the US military helped drive the Taliban government out of power in November, 2001.

With the increase in violence in Afghanistan, more Canadian troops and military assets were sent to take part in military operations there. In March 2008, Canadian parliament voted to extend Canadian military operations through 2011. By July that year, a total of roughly 41,000 Canadians will have served in the Afghan theatre of operations. ${ }^{52}$ According to an estimate it will cost Canadian taxpayers a whopping eight billion dollars to keep the Canadian forces and carry out military operations in Afghanistan. ${ }^{53}$ Some Canadians have been asking whether this amount of money could have been used for other purposes in Afghanistan. Canadian Muslim voices have joined in the criticisms by pointing out that the government of Afghanistan is run by warlords, and the government in Kabul is utterly corrupt. The Muslim organisations in Canada are concerned about an increase in Canadian casualties in Afghanistan. They have demanded that Canadian troops be withdrawn from Afghanistan as soon as possible. 


\section{Conclusions and Recommendations}

Canadian Muslims have emerged with a strong voice in their country's national and foreign policy issues.

- Whether the Maher Arar case, the Toronto terror plot, the anti-terror law or the controversy over 'reasonable accommodation', the Canadian Muslims participate in the national debate passionately - and they should continue to do so.

- Although the top priority of Canadian Muslims remains the integration of the community into Canadian society, the Canadian Muslims, just like other members of the Canadian society, take part in debates over foreign policy issues. They are concerned about the other members of the world Muslim community. Whether it is Iraq, Afghanistan or the Arab-Israeli conflict, Canadian Muslims have forcefully expressed their opinion. The Canadian authorities would do well to see the involvement of 'their' Muslims in public debates an asset rather than a threat.

\section{Notes}

1. Sheila McDonough and Sajida Alvi, "The Canadian Council of Muslim Women: A Chapter in the History of Muslim Women in Canada," The Muslim World 93 (2002), 80.

2. "Look Out Europe, They Say", The Economist, 24 June 2006, 28.

3. Akbar S. Ahmed, Islam under Siege: Living Dangerously in A Post-Honour World (London: Polity Press, 2003).

4. Ze'ev Maghen, "The Merry Men of Medina: Comedy and Humanity in the Early Days of Islam," Der Islam 83, no. 2 (July 2008), 278.

5. Ibid.

6. Ibid.

7. Ibid.

8. Ira M. Lapidus, “A Sober Survey of Islamic World,” Orbis 40, no. 3 (Summer 1996), 279.

9. John C. Thompson and Joe Tarlej, Other People's Wars: A Review of Overseas Terrorism in Canada (Toronto: The Mackenzie Institute, 2002), 48.

10. Ibid.

11. Marina Jiminez, "Women's Rights Trump Cultural Habits, Poll Finds," The Globe and Mail, 14 November, 2006.

12. Sumaira Sheikh, "Waiting to Change My Country - Canada," International Journal 63, no. 1 (Winter 2007), 125.

13. http://www.maherarar.ca/mahers\%20story.php (accessed on 10 May 2011).

14. CAIR-CAN and CAF, Opening Statement to Commission of Enquiry into the Actions of Canadian Officials in Relation to Maher Arar (Ottawa: CAIR-CAN and CAF, 14 June 2004), 3.

15. http://www.wikipedia.org/wiki/2006_Toronto-terrorism-case (accessed on 10 May 2011).

16. http://www.wapedia.mobi/en/2006_Toronto_terrorism_case (accessed on 10 May 2011).

17. http://wapedia,mobi/en/2006_Toronto_terrorism-case (accessed on 10 May 2011).

18. http://www.cbc.ca/news/background/toronto-bomb-plot/shaikh.html (accessed on 10 May 2011).

19. http://www.altmuslim.com/a/a/print/2368/ (accessed on 10 May 2011). 
20. http://www.ctv.ca/servlet/ArticleNews/story/CTVNews/20070208/celil_070208/2007/0208?hub= TopStories\&s-Name (accessed on 10 May 2011).

21. Daniel Marc Weinstock, "Multicultural Growing Pains," Library Review of Canada (JanuaryFebruary 2008), 28.

22. Lars von Törne, "Multicultural Misunderstandings," International Journal (Summer 2008), 554.

23. Weinstock, "Multicultural," 28.

24. Lars von Törne, "Multicultural," 553.

25. Ibid.

26. Robin Maynard and Sophie Le-Phat Ho, "Accommodate This! A Feminist and Anti-Racist Response to the 'Reasonable Accommodation' Hearings in Quebec," Canadian Women Studies 27, nos. 2-3 (2009), 21.

27. Ibid.

28. Ibid.

29. Weinstock, "Multicultural," 28.

30. Ibid.

31. Gerard Bouchard and Taylor, Charles Taylor, Building the Future: A Time for Reconciliation (Montreal: Bibliotheque et Archives Nationales du Quebec, 2008), 17.

32. Janice Gross Stein et. al., Uneasy Partners: Multiculturalism and Rights in Canada (Waterloo, Ontario [Canada]: Wilfrid Laurier University, 2007).

33. Ibid.

34. Ibid.

35. Ibid.

36. Weinstock, "Multicultural," 29.

37. Howard Leeson, Canadian Foreign Policy and the Events of September 11: A Dramatic Turn (Regina, Saskatchewan [Canada]: Saskatchewan Institute of Public Policy, University of Regina, 2002), 5 .

38. Government of Canada, A Dialogue on Foreign Policy (Ottawa: Department of Foreign Affairs and International Trade, 2003), 3.

39. Ibid., 3-4.

40. Liat Redcliff Ross, "Canadian Muslims and Foreign Policy," International Journal 63, no. 1 (Winter 2007-2008), 187-205.

41. Ibid., 187.

42. Ibid, 188.

43. Canadian Arab Federation, Policy Position: Foreign Policy (Ottawa: Canadian Arab Federation, 2006), 1.

44. Ibid.

45. Ibid.

46. Wahida Valentine, Living Conditions in the Gaza Strip and the West Bank (Ottawa: Canadian Islamic Congress, 2005), 3.

47. Canadian Islamic Congress and Canadian Arab Federation, Call On All Canadians to Condemn Israeli War Crimes in Gaza (Ottawa: CIC and CIF, 21 January 2009), 1.

48. Ibid.

49. Canadian Arab Federation, Policy Position: National Security (Ottawa: Canadian Arab Federation, 27 March 2009), 1.

50. Ibid.

51. Ibid.

52. David Perry, “Canada's Seven Billion Dollar War," International Journal 63, no. 3 (Summer 2008), 703.

53. Ibid. 